\title{
Employment and employment characteristics during the current crisis in Groatia
}

\author{
GORAN VUKŠIĆ, Institute of Public Finance
}

The current economic crisis has put many private companies, but also state owned enterprises and other public sector entities under pressure to cut costs. Many of them reduced employment, and/or wages of their employees. In addition to these negative effects, there have been changes in other employment characteristics. This Newsletter presents trends in employment and employment characteristics as they occurred during the current crisis and provides key points of the analysis conducted at the Institute of Public Finance with support from Friedrich Ebert Stiftung.

\section{EMPLOYMENT AND WAGES - AGGREGATE TRENDS}

The first section presents the aggregate trends in employment and real gross wages for the period between 2000 and 2012. The pre-crisis period is defined as being from 2000 to 2008 , while the period after 2008 is considered to be the crisis period. This corresponds to the real GDP growth rates which were positive between 2000 and 2008 and negative afterwards (i.e. equal to zero in 20II). ${ }^{\mathrm{I}}$ As shown in table I, over the entire observed period, Croatian economy has been characterized by low employment and high unemployment rates. The employment rate first declined in 2001 and again in 2003 and 2005 . It rose during other pre-crisis years and reached the peak in 2008. It has been constantly decreasing during the crisis. The unemployment rate was decreasing continuously before 2008, after which a steady increase began.

\section{Table I}

Employment and unemployment rates, in \%

\begin{tabular}{|c|c|c|c|c|c|c|c|c|c|c|c|c|c|}
\hline & 2000 & 2001 & 2002 & 2003 & 2004 & 2005 & 2006 & 2007 & 2008 & 2009 & 2010 & 2011 & 2012 \\
\hline Employment rate & 42.6 & $4 \mathrm{I} .8$ & $43 \cdot 3$ & 43.I & 43.5 & $43 \cdot 3$ & 43.6 & 44.2 & $44 \cdot 5$ & 43.3 & 4I.I & 39.5 & 38.I \\
\hline Unemployment rate & I6.I & I5.8 & I4.8 & I 4.3 & I3.8 & I2.7 & II. 2 & 9.6 & 8.4 & 9.I & II. 8 & I3.5 & I5.8 \\
\hline
\end{tabular}

Source: CNB (2000-2013 - Economic Indicators). Definitions of employment and unemployment rate according to International Labor Organization (ILO): population older than I5 years of age.

${ }^{\text {I }}$ Source: CNB (2000-20I3 - Economic Indicators). 
Figure I shows aggregate trends in employment and real gross wages (in 2005 prices). There are three employment indicators: I) employment in legal persons which represents the largest single segment of total employment; 2) employment in legal persons (first indicator) plus employment in crafts, trades and freelances; and 3) total employment - employment in legal persons and crafts, trades and freelances (second indicator) plus insured private farmers. ${ }^{2}$ All three employment indicators reached their peaks in 2008. In the period between 2000 and 2008, employment in legal persons increased by almost $19 \%$. This was followed by a decline of nearly $8 \%$ during the crisis period. Employment in crafts, trade and freelances rose by slightly more than $29 \%$ in the pre-crisis period, but its decline during the crisis was also more pronounced and it amounted to almost $20 \%$. Contrary to the trend for these two groups of employees, number of insured private farmers has been decreasing over the whole period under observation: by around $52 \%$ before the crisis and by an additional $24 \%$ after 2008 . The average real gross wage in legal persons was steadily rising until reaching its peak in 2008, with cumulative increase over the pre-crisis period amounting to almost 22\%. The crisis brought a decline in amount of nearly $5 \%$.

If one considers employment in legal persons only and compares it to the real wage developments, both of these variables in 2012 (II53 thousand employees with the average real gross wage of HRK 6395) were slightly below their respective levels in 2006 (II60 thousand employees with the average wage in the amount of HRK 6428). Although relative employment decline in legal persons was stronger than real wage decline (as described by negative growth rates), employment increases between 2006 and 2008 were also stronger than wage increases. However, the adjustment in crisis for this, largest segment of employees, was more pronounced on the employment reduction side in the first two years of the crisis (as in other Eastern European countries, according to Cho and Newhouse, 2013), while real wages declined faster than employment in 2012 (in 2011 the intensity of adjustment was roughly the same).

\section{Figure I}

Real (gross) wages in legal persons (right axis, in HRK) and employment (left axis, in thousand)

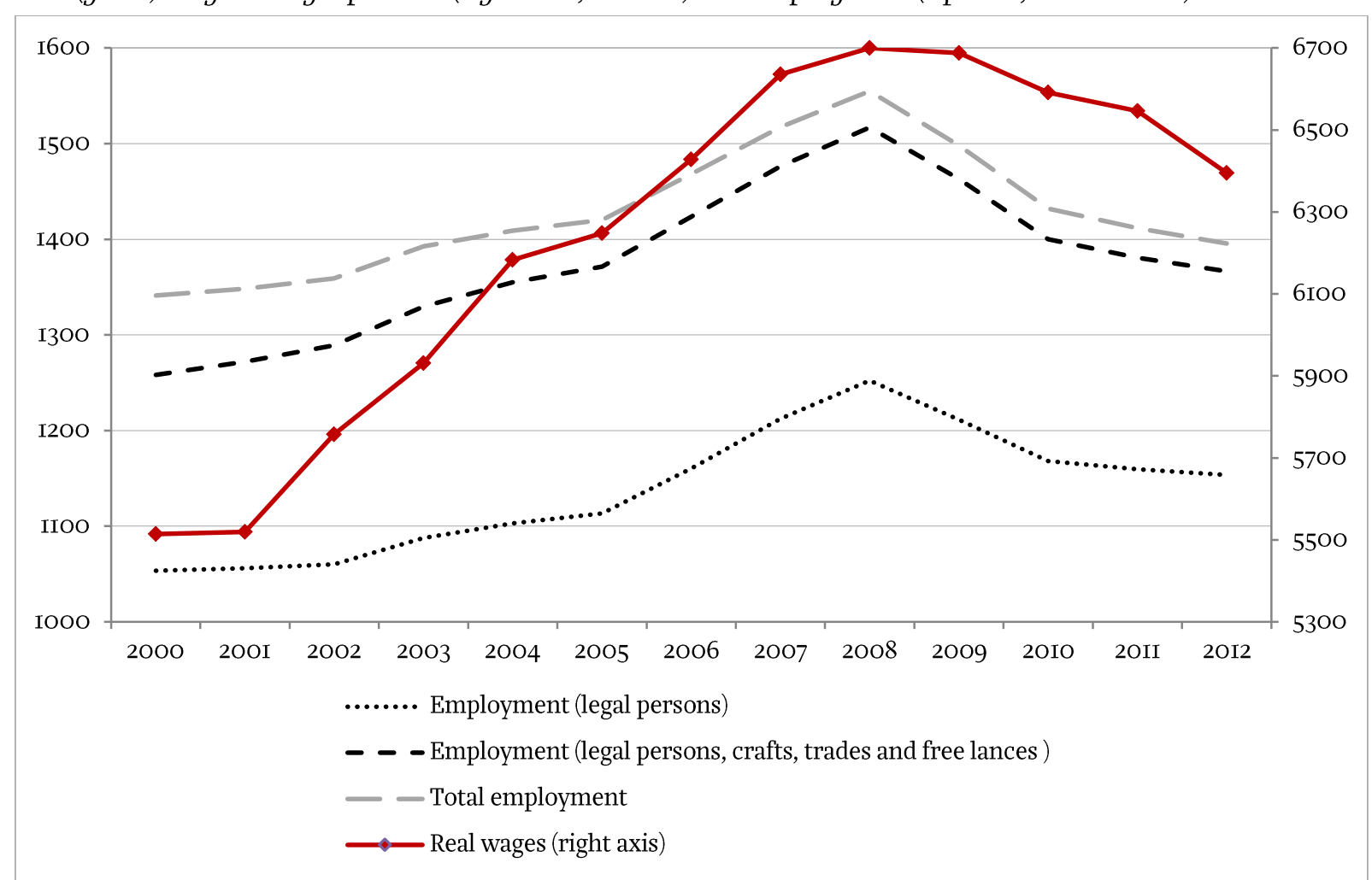

Source: CBS, real wages in 2005 prices.

${ }^{2}$ Methodology and definitions are available in the Croatian Bureau of Statistics (CBS) publication: Statistical Yearbook of the Republic of Croatia (chapters 6 and 7). 


\section{SEGTORAL DEVELOPMENTS OF EMPLOYMENT AND REAL WAGES IN LEGAL PERSONS}

This part presents data on the sectoral developments of real gross wages and employment in legal persons for the period between 2000 and 2012.3 Table 2 shows growth in employment and real gross wages I) from 2000 to 2008 ; 2) from 2008 to 2012; and 3) for the whole period from 2000 to 2012, for 19 sections of economic activity.

Table 2

Sectoral developments of employment and real gross wages in legal persons, in \%

\begin{tabular}{|c|c|c|c|c|c|c|c|}
\hline & & \multicolumn{3}{|c|}{ Employment } & \multicolumn{3}{|c|}{ Real wages } \\
\hline & & $\mathbf{I}$ & 2 & 3 & 4 & 5 & 6 \\
\hline & Changes in periods: & $2008 / 00$ & $2012 / 08$ & 2012/00 & $2008 / 00$ & $2012 / 08$ & 2012/00 \\
\hline \multicolumn{8}{|c|}{ Sectors (sections): } \\
\hline A & Agriculture, forestry and fishing & $-\mathrm{I} 2.3$ & $-4 . I$ & -15.9 & 20.7 & -3.2 & 16.8 \\
\hline B & Mining and quarrying & 8.1 & -36.8 & -31.7 & $55 \cdot 3$ & $-\mathrm{IO} .4$ & 39.2 \\
\hline C & Manufacturing & -0.3 & -16.7 & -16.9 & 27.3 & -4.9 & 21.0 \\
\hline $\mathrm{D}$ & $\begin{array}{l}\text { Electricity, gas, steam and air } \\
\text { conditioning supply }\end{array}$ & -7.4 & $-\mathrm{I} .9$ & -9.2 & 26.0 & 0.0 & 26.0 \\
\hline $\mathrm{E}$ & $\begin{array}{l}\text { Water supply; sewerage, waste } \\
\text { management and remediation } \\
\text { activities }\end{array}$ & 3I.3 & 3.8 & 36.2 & 21.2 & -6.7 & I3.I \\
\hline $\mathrm{F}$ & Construction & 65.4 & -27.4 & 20.0 & 38.5 & -IO.I & 24.4 \\
\hline G & $\begin{array}{l}\text { Wholesale and retail trade; repair of } \\
\text { motor vehicles and motorcycles }\end{array}$ & 45.7 & $-\mathrm{I} 6.6$ & $2 \mathrm{I} .5$ & 3I.9 & -5.7 & 24.5 \\
\hline $\mathrm{H}$ & Transportation and storage & 2.2 & -8.6 & -6.6 & 36.3 & -4.9 & 29.6 \\
\hline I & $\begin{array}{l}\text { Accommodation and food service } \\
\text { activities }\end{array}$ & 21.7 & - -1.6 & 19.8 & 28.2 & $-4 \cdot 3$ & 22.7 \\
\hline $\mathrm{J}$ & Information and communication & I9.9 & 4.0 & 24.7 & I5.5 & O.I & I5.6 \\
\hline $\mathrm{K}$ & Financial and insurance activities & 25.6 & I.4 & 27.3 & I5.3 & -I.I & I4.I \\
\hline $\mathrm{L}$ & Real estate activities & I25.7 & 20.4 & I7I. 8 & $\mathrm{I} 2.7$ & -5.6 & 6.4 \\
\hline M & $\begin{array}{l}\text { Professional, scientific and } \\
\text { technical activities }\end{array}$ & 54.9 & -2.5 & 51.0 & 50.4 & - II. 2 & 33.6 \\
\hline $\mathrm{N}$ & $\begin{array}{l}\text { Administrative and support service } \\
\text { activities }\end{array}$ & I05.8 & I3.6 & I33.8 & -3.9 & $-\mathrm{I} 4 . \mathrm{O}$ & $-\mathrm{I} 7 \cdot 3$ \\
\hline $\mathrm{O}$ & $\begin{array}{l}\text { Public administration and defense; } \\
\text { compulsory social security }\end{array}$ & $-\mathrm{I} 2.9$ & -0.2 & $-\mathrm{I} 3 . \mathrm{I}$ & 2.7 & -4.7 & -2.2 \\
\hline $\mathrm{P}$ & Education & 21.8 & 7.5 & 30.9 & $\mathrm{I} 4.8$ & -3.5 & IO.8 \\
\hline Q & $\begin{array}{l}\text { Human health and social work } \\
\text { activities }\end{array}$ & $\mathrm{I} 3.2$ & 6.9 & 21.0 & 8.7 & -6.8 & I.3 \\
\hline $\mathrm{R}$ & Arts, entertainment and recreation & 75.6 & 6.3 & 86.6 & 22.2 & -8.9 & II.3 \\
\hline \multirow[t]{6}{*}{$S$} & Other service activities & 46.I & $\mathrm{I} .2$ & 47.8 & 20.2 & -4.7 & I4.6 \\
\hline & Total economy & I8.9 & -7.9 & 9.5 & 21.5 & -4.6 & I6.0 \\
\hline & \multicolumn{7}{|l|}{ Descriptive statistics by sections: } \\
\hline & Minimum & $-\mathrm{I} 2.9$ & -36.8 & -31.7 & -3.9 & $-\mathrm{I} 4 . \mathrm{O}$ & -17.3 \\
\hline & Maximum & I25.7 & 20.4 & I7I. 8 & $55 \cdot 3$ & O.I & 39.2 \\
\hline & Mean & 33.2 & -2.7 & 3I.5 & 23.3 & -5.8 & I6.I \\
\hline
\end{tabular}

Source: author's calculations based on data from CBS.

In the pre-crisis period, the majority of economic activities saw an increase in employment, with the highest growth recorded in the following sections: $L$ Real estate services; $N$ Administrative and support services; and R Arts, entertainment and recreation. However, there have been activities in which employment shrunk during the good times before the crisis, with the strongest declines recorded in 
sections: O Public administration and defense, compulsory social security; A Agriculture, forestry and fishing; and D Electricity, gas, steam and air conditioning supply. Employment growth (in legal persons) in the overall economy during the pre-crisis period amounted to almost $19 \%$.

Real wages, on the other hand, grew in all economic activities before the crisis, except in section $\mathrm{N}$ Administrative and support services, where a slight decline was recorded. Interestingly, this is the section with the second largest employment growth. The largest increases in real wages can be observed in sections: B Mining and quarrying (a rather small section with respect to number of employees); M Professional, scientific and technical activities; and F Construction. The growth of real gross wages before the crisis for the whole economy approximately equaled $22 \%$.

During the crisis, employment declined in Io out of 19 sectors of economic activities, with the largest fall recorded in: B Mining and quarrying; F Construction; and C Manufacturing. Interestingly, employment in the three sections with the highest pre-crisis employment growth continued to increase during the crisis. Overall economy employment (in legal persons) decreased by nearly $8 \%$ during the crisis.

Real wages, on the other hand, declined in 17 out of I9 activities after 2008 and the fall for the whole economy equaled almost $5 \%$. One can observe substantial heterogeneity in sectoral developments of employment and wages in the crisis, given the fact that not all activities were equally exposed to negative economic shock and/or had quite different adjustment patterns. For example, section $\mathrm{N}$ Administrative and support service activities experienced the second largest increase in employment but also the largest drop in wages during the crisis, while the two sectors with the largest employment cuts in the crisis were also characterized by comparatively large declines in real wages (sections B Mining and quarrying and F Construction).

\section{EMPLOYMENT GHARAGTERISTIGS}

Table 3 provides data on developments of a number of employment characteristics in legal persons in the period from 2000 to 2012 . The data in the table is restricted to legal persons, as these indicators are available only for this employment segment. The first part of table 3 shows the number of workers by ownership: state, private and mixed ownership (and workers in cooperatives, which is a negligible segment as regards the number of employees). These data are not shown in shares as most of other indicators, since it is particularly interesting to see whether, especially during the crisis, the actual number of workers has been decreasing or increasing in legal entities with a specific type of ownership. It is clear that the private sector contributed the most to employment increases prior to the crisis. Although this may partly result from the privatization process, the number of jobs in privately owned entities increased by a much larger number than the absolute value of net jobs loss in other legal persons. At the same time, the number of employees in entities with mixed ownership decreased substantially, while that in the public sector (entities in state ownership) slightly rose. ${ }^{4}$ However, while this slight increase in the number of public sector workers continued throughout the crisis as well, a number of jobs in private companies were lost (employee numbers dropped from 689 thousand in 2008 to 645 thousand in 2012) and the decline in the number of employees in entities with mixed ownership continued at a faster rate.

The share of women employment was slightly decreasing in the beginning of the observed period, but started increasing after 2004. During the crisis, the rise in the share of women employment accelerated,

\footnotetext{
${ }^{4}$ Again, the privatization of state owned enterprises should have a negative partial effect on the number of public sector employees. However, it may cause an increase in the number of employees in entities with private and/or mixed ownership, depending on whether a company was fully privatized. Furthermore, there may be cases in which the state as the co-owner (in case of mixed ownership) decides to sell its (remaining) shares, which means a (further) privatization of firms in mixed ownership. This should, per se, then lead to an increase in private sector employment and to a decline in the number of employees in entities with mixed ownership.
} 
reaching its peak in 2012 when it amounted to nearly $47 \%$. Thus, it seems that men workers have been hit harder by the crisis than women workers.

As for the groups of employees by age, the shares for the three groups have been roughly constant in the pre-crisis period, but after 2008, the share of young workers (younger than 25 years of age) decreased from $7.2 \%$ in 2008 to only $4.4 \%$ in 2012, which is the lowest value during the observed period. After 2008, this development went hand in hand with a slight increase in share of workers between 25 and 59 years of age and a more pronounced rise in the share of employees aged 60 or older.

Looking at the data on employment shares by educational attainment, one observes clear trend of steady share decrease for the group of workers with comparatively lower education (basic school, highly skilled, skilled, semi-skilled and unskilled) throughout the whole period. Exactly the opposite trend can be seen in the shares of workers with secondary school education and those with higher levels of education.

The next two indicators refer to shares of workers by type of employment (employed for an unspecified period of time, fixed period of time or as trainees), and to employees by contractual working time (full, part or short time workers). Obviously, employees for an unspecified period of time dominate over the whole period under observation, but their share is characterized by a slowly diminishing trend before the crisis, reaching the lowest values in 2007 and 2008, followed by a small increase over the following two years and a slight decline in 2011 and 20I2. Since the share of trainees has been rather constant (and low), data on workers employed for fixed period of time give a mirror picture of those employed for an unspecified period, i.e. their share reached its peak of more than $13 \%$ in 2007 . Interestingly, there have been stronger annual increases in the share of fixed term employees between 2000 and 2003, than after the Labor Act amendments in 2003 which lowered the Employment Protection Legislation index for fixed term employment, by introducing regulation of temporary employment agencies (Matković and Biondić, 2003).

The share of full time employees was rather constant in the pre-crisis period and exceeded $98 \%$ in each of these years. In the crisis, however, this share declined slightly, but steadily from $98.2 \%$ in 2008 to $97.1 \%$ in 2012. While the share of short time workers remained largely unchanged after 2002 (and rather small), the share of part time employees rose from $1.2 \%$ in 2000 to $2.7 \%$ at the end of the observed period. Thus, although their share is still very small, it has more than doubled, mostly in the crisis years.

The last part of table 3 shows data on hours worked. These are available only for the period until 2011 and do not display any strong upward or downward trends, either overall, or in the periods before and during the crisis. There is a slight decline in the total number of hours and the hours actually worked in the crisis, but these numbers were also declining in part of the period before the crisis, i.e. this is not something specific for the crisis period. The only exception in this respect is the number of overtime hours per worker which reached highest values in period between 2006 and 2008, after which there has been a significant decline. 
Table 3

Characteristics of employment in legal persons, 2000-2012

\begin{tabular}{|c|c|c|c|c|c|c|c|c|c|c|c|c|c|}
\hline & 2000 & 2001 & 2002 & 2003 & 2004 & 2005 & 2006 & 2007 & 2008 & 2009 & 2010 & $20 I I$ & 2012 \\
\hline \multicolumn{14}{|l|}{ Employment by type of ownership (in thousand) } \\
\hline Private & 339 & 407 & 444 & 482 & 533 & 548 & 592 & 652 & 689 & 675 & $65 \mathrm{I}$ & 639 & 645 \\
\hline State & $39 \mathrm{I}$ & 456 & 436 & 425 & $4 \mathrm{I} 9$ & 402 & 420 & $4 \mathrm{I} 2$ & 422 & 427 & 426 & 427 & 435 \\
\hline Mixed & 204 & I83 & I69 & I66 & 140 & I46 & $\mathrm{I} 29$ & $\mathrm{I} 29$ & $\mathrm{I} 24$ & II2 & 86 & $8 \mathrm{I}$ & 66 \\
\hline Cooperative & 4 & 3 & 3 & 3 & 3 & 3 & 3 & 3 & 3 & 3 & 4 & 4 & 2 \\
\hline \multicolumn{14}{|l|}{ Employment by sex (in \%) } \\
\hline Women & 45.5 & $45 \cdot 3$ & 44.9 & 44.7 & 44.7 & 45.0 & 45.0 & 45.I & 45.2 & 45.6 & 46.3 & 46.6 & 46.9 \\
\hline \multicolumn{14}{|l|}{ Employment by age (in \%) } \\
\hline Younger than 25 & 7.0 & 6.7 & 6.8 & 6.9 & 6.8 & 6.5 & 6.7 & 6.9 & 7.2 & 6.5 & 5.3 & 4.9 & 4.4 \\
\hline $25-59$ & 91.5 & 91.6 & 91.4 & 91.2 & 91.2 & 91.5 & 9I.I & 90.5 & 9O.I & 90.2 & 90.9 & 91.2 & 91.2 \\
\hline 60 and older & I.5 & I.7 & $\mathrm{I} .8$ & 1.9 & I.9 & $2 . I$ & 2.2 & 2.5 & 2.7 & 3.2 & 3.7 & 3.9 & 4.4 \\
\hline \multicolumn{14}{|l|}{ Employment by educational attainmenta ${ }^{\mathrm{a}}$ (in \%) } \\
\hline Higher (college and university degree or higher) & 22.2 & 23.0 & 23.3 & 23.5 & 23.5 & 24.I & 24.4 & 24.6 & 24.9 & 25.7 & 27.2 & 28.I & 29.0 \\
\hline Secondary & 36.7 & 38.0 & $39 \cdot 3$ & 40.9 & 43.4 & 44.0 & 44.9 & 46.0 & 47.2 & 48.0 & 48.0 & 48.4 & 48.7 \\
\hline Lower (all other employees) & 4I.I & 39.0 & 37.4 & 35.6 & 33.I & 3I.8 & 30.6 & 29.3 & 27.9 & 26.3 & 24.9 & 23.5 & 22.3 \\
\hline \multicolumn{14}{|l|}{ Employment by type (in \%) } \\
\hline For unspecified period of time & 91.6 & 90.I & 88.7 & 87.I & 86.9 & 87.2 & 86.4 & 85.9 & 85.9 & 87.3 & 87.9 & 87.4 & 86.8 \\
\hline For fixed period of time & 7.6 & 9.2 & 10.5 & I2.I & $\mathrm{I} 2.2$ & I2.I & $\mathrm{I} 2.8$ & 13.4 & 13.2 & 12.0 & II. 4 & II.9 & $\mathrm{I} 2.5$ \\
\hline Trainees & 0.8 & 0.8 & 0.8 & 0.8 & 0.8 & 0.7 & 0.8 & 0.7 & 0.9 & 0.7 & 0.7 & 0.7 & 0.7 \\
\hline \multicolumn{14}{|l|}{ Employment by contractual working time (in \%) } \\
\hline Full time & 98.3 & 98.2 & 98.4 & 98.3 & 98.3 & 98.2 & 98.2 & 98.I & 98.2 & 98.0 & 97.7 & 97.5 & 97.I \\
\hline Part time & $\mathrm{I} .2$ & I.3 & I.3 & $\mathrm{I} .4$ & I.4 & I.5 & I.6 & I.7 & I.6 & I.8 & $2 . I$ & 2.3 & 2.7 \\
\hline Short time & 0.5 & 0.5 & 0.3 & 0.3 & 0.3 & 0.3 & 0.2 & 0.2 & 0.2 & 0.2 & 0.2 & 0.2 & 0.2 \\
\hline \multicolumn{14}{|l|}{ Hours worked ${ }^{\text {a }}$, hours by employee } \\
\hline \multirow{4}{*}{$\begin{array}{l}\text { Total number of hours per worker } \\
\text { Hours actually worked } \\
\text { Hours not actually worked - paid within the legal entity } \\
\text { Hours not actually worked - paid out of a legal entity }\end{array}$} & 2116 & $2 \mathrm{IO} 4$ & 2091 & 2087 & 2096 & 2080 & 2079 & $208 \mathrm{I}$ & 2089 & 2075 & 2073 & 2064 & \\
\hline & I7I9 & 1720 & 1708 & $\mathrm{I} 7 \mathrm{I} 8$ & 1727 & 1712 & I7OI & 1688 & 1696 & 1687 & I694 & 1689 & \\
\hline & 277 & $27 \mathrm{I}$ & 274 & 273 & 269 & 262 & 264 & 275 & 269 & 275 & 270 & 269 & \\
\hline & 97 & 88 & 79 & 66 & 69 & 75 & 80 & 84 & 9I & 88 & 88 & 84 & \\
\hline Non-paid hours & 2 & $\mathrm{I}$ & $\mathrm{I}$ & $\mathrm{I}$ & 2 & 2 & 2 & $\mathrm{I}$ & $\mathrm{I}$ & $\mathrm{I}$ & $\mathrm{I}$ & I & \\
\hline Overtime hours & $2 \mathrm{I}$ & 24 & 28 & 29 & 29 & 29 & 32 & 33 & 32 & 24 & 20 & $2 \mathrm{I}$ & \\
\hline
\end{tabular}

aDefinitions are available in the Croatian Bureau of Statistics (CBS) publication: Statistical Yearbook of the Republic of Croatia - chapter 6.

Source: CBS and author's calculations based on CBS data. 
Further analysis included performing a number of simple regressions, using sectoral data at the level of 74 divisions of economic activity, for the period 2009-2012, in order to reveal potentially significant partial correlations between different variables. Dependent variables in regressions were the growth of real gross wages and changes in employment shares by ownership, sex, age, education, type of employment and by contractual working time. The set of independent variables varied for different dependent variables, but it always included sectoral employment growth and the share of employment by type of ownership. Details are not provided here. Instead, only conclusions derived from regressions yielding significant partial correlation coefficients for some variables, and from descriptive analysis presented above, are presented.

\section{EMPLOYMENT BY TYPE OF OWNERSHIP}

During the crisis, jobs were lost in the private sector and in entities in mixed ownership, while the number of jobs in the public sector (entities in state ownership) slightly increased. There seems to be more labor dynamics in the private sector segment, as the employment share of private sector workers increased (i.e. decreased) in economic activities with positive (i.e. negative) employment growth.

\section{SECTORAL REAL WAGE GROWTH}

The growth of sectoral real wages in the crisis is positively and significantly related to the growth of macroeconomic wage underlying the importance of broader macroeconomic conditions for sectoral wage dynamics found in earlier research (Vukšić 2012). There is also a positive and significant partial correlation between employment and wage growth. Wage growth in the crisis period is negatively related to the sectoral share of private sector employees; and positively related to the share of workers in entities in mixed ownership. Results for wage growth in the public sector are similar to those in the private sector, but the relationship is weaker and statistically less convincing.

\section{EMPLOYMENT SHARE OF WOMEN}

There is a positive simple correlation between the employment share of women and sectoral employment growth indicating that economic activities with comparatively higher employment share of women experienced less employment cuts or higher employment growth rates. Changes in the share of women employment, on the other hand, are not significantly related to sectoral employment growth, but increases in the employment share of women were stronger in economic activities with comparatively higher shares of public sector employment.

\section{EMPLOYMENT BY AGE}

Aggregate data on employment by age groups show a declining share of younger workers (under 25) during the crisis. This may result from the low number of new job openings and the fact that the existing workers naturally shift to older age categories. Shares of employees aged between 25 and 59 decrease with increasing sectoral employment, while the opposite effect can be observed for the other two groups. In addition, the change in the shares of young employees is positively (i.e. negatively) related to the share of private (i.e. public) sector workers, while the opposite holds true for employees aged 6o or older.

\section{EMPLOYMENT BY EDUCATIONAL LEVEL}

Employees with comparatively lower educational attainment face severe challenges in the labor market. Their declining share in total employment is a longer term trend, not specific to the crisis period. The corresponding shares for employees with secondary education and those with higher educational 
attainment show the opposite trend. Sectors with larger shares of workers with higher education experienced less employment cuts, i.e. higher employment growth rates. The results of regression analysis imply that employees with higher education are more strongly represented among the newlyemployed than among existing employees in sectors with increasing employment, but also among those leaving (or being laid off) in shrinking economic activities. The opposite holds true for workers with lower and secondary education. Results also indicate that state ownership may be connected with a higher level of protection for the group of employees with lower educational attainment.

\section{EMPLOYMENT BY TYPE (FOR FIXED AND FOR UNSPECIFIED PERIOD OF TIME)}

Positive and significant correlation between sectoral employment growth and changes in sectoral share of employees with fixed-term contracts is found across a large majority of different regression approaches. This suggests that, in activities with increasing employment, workers with fixed term contracts are represented more among newly employed than among existing employees. Vice versa, in sectors with declining employment, this segment of employees is exposed to over-proportional probability of losing a job (either by being laid off, or by not getting contract renewal), leaving for other reasons, or becoming permanently employed (which does not seem very likely in times of crisis). Sectors with higher shares of younger workers experience stronger increases in fixed term employment shares. The results according to employment by ownership clearly show that a comparatively higher share of employees in the private sector is always associated with stronger increases in the share of fixed term employment. This indicates that the increasing importance of this, more flexible form of employment (during the last two years of the crisis), has been stronger in the more dynamic labor market segment, i.e. the private sector.

\section{EMPLOYMENT BY CONTRAGTUAL WORKING TIME}

The share of part time employees, although still very small, has increased substantially during the crisis. Results of regression analysis imply that there is an over-proportionate share of the part time workers among newly employed in sectors with increasing employment. Vice versa, in sectors with declining employment, part time employees are exposed to over-proportional probability of losing a job or leaving for other reasons (there is also a possibility that some are afterwards employed as full-time workers, but it does not seem very likely in times of crisis and employment cuts). This suggests the increasing importance of this more flexible form of employment, i.e. part time work, during the crisis, which has been more pronounced in economic activities with comparatively large shares of women employees, employees with higher education and fixed term employees.

\section{SUMMARY OF CONCLUSIONS AND SOME REMARKS}

The main findings of the analysis can be summarized as follows:

- The primal (aggregate) mode of adjustment to the crisis was a decline in employment, although the intensity of decline in real wages exceeded that of employment reduction in the last observed year, i.e. 2012. There are, however, considerable differences in adjustment patterns across economic activities.

- During the crisis, jobs were lost in the, more dynamic, private sector, while the number of jobs in the public sector (entities in state ownership) slightly increased. Jobs were also lost in entities in mixed ownership during the crisis, but this is a continuation of a longer term trend.

- Economic activities with comparatively larger shares of women in employment have experienced less employment cuts and the aggregate employment share of women rose in the crisis. Their share increased more strongly in activities with a larger share of public sector workers.

- There is a declining share of younger workers during the crisis. 
- Employees with comparatively lower educational attainment face severe challenges in the labor market, which is a longer term trend, not specific to the crisis period. There are indications that this group of employees enjoys a higher level of protection in the public sector.

- Analysis also shows a rising significance of more flexible forms of employment: the share of fixed term employees has been increasing during the last two observed years, especially in economic activities with larger shares of private sector employment and younger workers. Similarly, the share of part time workers increased during the crisis, particularly in activities with comparatively large shares of women employees, those with higher education and fixed term employees.

- Working hours do not exhibit any strong trends that would be specific to the crisis, except for the diminishing number of overtime hours per worker.

The fact that the intensity of adjustment to crisis on the employment side has been stronger than on the side of wages (especially during the first two years of the crisis) implies that costs of crisis have been unevenly shared among workers in the sense that some lost all of their labor income. This puts the unemployment benefits aspect of the social system, i.e. policies which should mitigate the negative consequences of complete, or at least severe, labor income losses, at the center of interest (see Khanna et al. 2010). In the context of the concentration of social consequences on laid off workers, Matkovic et al. (2OIO) suggest that it increases the general level of insecurity and that its alternative is to have a more even distribution of risks, e.g. through a social pact on wages or measures relating to the efficient distribution of working hours.

However, even if wages are rigid, the government may use fiscal instruments to lower labor costs generally, by altering the structure of budget revenues and shifting the tax (including social contributions) burden away from labor income. This could have positive effects on labor demand and it could make it easier for employers to keep more workers in the present crisis. Unfortunately, the only policy measure taken to that end (reduction of health insurance contributions paid by the employer by 2 percentage points from May 2012) turned out to be only temporary.

Results also indicate that the position of young workers deteriorated significantly during the crisis, which calls for policy makers to take an active role in coming up with tailored measures facilitating employment for this age group, and/or promoting their further education. The latter should relieve the pressures on the labor supply side, and increase young people's employment chances in the future as the evidence shows a clear trend of stronger demand for workers with higher educational attainment (this is also an argument in favor of promoting adult education and lifelong learning).

\section{REFERENCES}

Cho, Y. and Newhouse, D., 2013. How Did the Great Recession Affect Different Types of Workers? Evidence from 17 Middle-Income Countries. World Development, 4I(C), pp. 3I-5O.

CBS, 200I-13. Statistical Yearbooks. Zagreb: Croatian Bureau of Statistics.

CNB, 2000-12. Bulletin. Zagreb: Croatian National Bank.

Khanna, G., Newhouse, D. and Paci, P., 2010. Fewer Jobs or Smaller Paychecks? Labor Market Impacts of the Recent Crisis in Middle-Income Countries. Economic Premise, br. II. Washington: The World Bank.

Matković, T. and Biondić, I., 2003. Reforma Zakona o radu i promjena indeksa zakonske zaštite zaposlenja. Financijska teorija i praksa, 27(4), str. 515-528.

Matković, T., Arandarenko, M. and Šošić, V., 20Io. Utjecaj ekonomske krize na tržište rada. Zagreb: UNDP. Vukšić, G., 20I2. Sectoral wage dynamics and intersectoral linkages in Croatia in the context of export competitiveness. The WIIW Balkan Observatory Working Papers, No. 99. 